\title{
Editorial
}

\section{Special Issue on the International Conference on Learning and Memory}

We are pleased to bring Learning and Memory's readership this special issue on some of the most recent and exciting advances in learning and memory, which were presented at the International Conference on Learning and Memory (LEARNMEM2018) in April 2018.

LEARNMEM2018 was held in Huntington Beach, California by the University of California, Irvine's Center for the Neurobiology of Learning and Memory (CNLM) to celebrate the 35th anniversary of the Center and to bring the field together to discuss the latest research in learning and memory, spanning across all levels of analysis.

The conference was attended by 1034 scientists from 35 countries and was supported by two National Institutes of Health grants and 32 commercial and nonprofit sponsors. Approximately half of the attendees and speakers, both invited and accepted, were women. The conference featured 35 symposia, 240 talks, 280 posters, and 16 plenary lectures, including a keynote by Nobelist Dr. Edvard Moser, co-director of the Kavli Institute for Systems Neuroscience at the Norwegian University of Science and Technology in Trondheim, Norway.

The significant attendance and participation at the International Conference on Learning and Memory, which will be held triennially, is a testament to the growth of the learning and memory field as well as the increasing desire for interdisciplinary dialogue and collaboration. It is our hope that this conference provides an opportunity to collectively tackle the grand challenges of our field.

In this special issue, we highlight seven recent empirical works from leaders in the field who participated in the conference.

Leal et al. present a new mnemonic discrimination task with naturalistic stimuli and show evidence that performance on the task is associated with the aggregation of tau protein in the medial temporal lobes. Van Kesteren et al. report new evidence for bias in recognition judgments based on perceptual similarity. Stickel et al. demonstrate that cardiovascular risk factors are associated with cognitive deficits, in particular, executive function, in Hispanics but not in non-Hispanic whites.

Noble et al. present a set of experiments demonstrating that vagus nerve stimulation produces an anxiolytic effect but it is not associated with the extinction of conditioned fear. Robin and Olsen provide new evidence that scene stimuli can boost episodic memory in an associative inference paradigm, suggesting that spatial context can be used to boost learning in educational settings. Ramanan et al. report on delayed recall performance in patients with Corticobasal Syndrome as well as links to frontotemporal and frontoparietal network connectivity dysfunction. Finally, Cohen et al. show that the learning of aversive odor associations strengthens episodic memory both in adolescents and adults, a relationship that may be mediated by autonomic arousal.

This special issue also includes two reviews. Allen et al. provide a thoughtful review of the thalamic nucleus reuniens and its role in memory and behavior. And finally, Baram et al. provide a comprehensive account of how spatial memory networks arise during development and how aberrant activity, such as early-life seizures, can lead to disruption of these networks.

We believe this special issue makes a very important contribution to the field of learning and memory and serves as an example of interdisciplinarity and integration across levels of analysis that are crucial to the advancement of science.

\author{
Manuella O. Yassa \\ Executive Director \\ International Conference on \\ Learning and Memory \\ Michael A. Yassa \\ Program Chair \\ International Conference on \\ Learning and Memory
}

(C) 2019 Yassa and Yassa This article is distributed exclusively by Cold Spring Harbor Laboratory Press for the first 12 months after the full-issue publication date (see http://learnmem.cshlp.org/site/misc/terms.xhtml). After 12 months, it is available under a Creative Commons License (Attribution-NonCommercial 4.0 International), as described at http://creativecommons.org/licenses/by-nc/ $4.0 /$. 


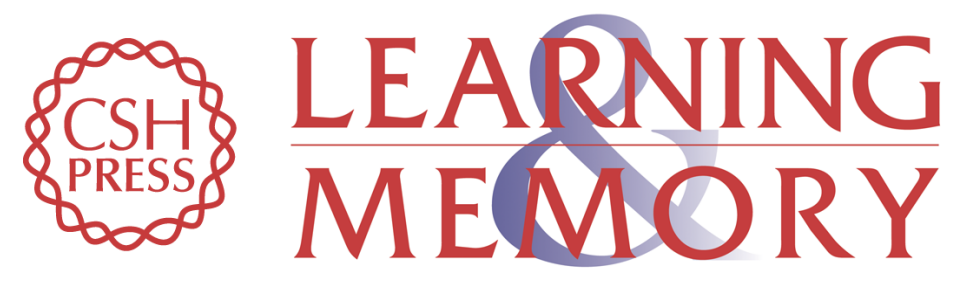

\section{Special Issue on the International Conference on Learning and Memory}

Manuella O. Yassa and Michael A. Yassa

Learn. Mem. 2019, 26:

Access the most recent version at doi:10.1101/Im.049957.119

$\begin{aligned} & \begin{array}{r}\text { Creative } \\ \text { Commons } \\ \text { License }\end{array} \begin{array}{l}\text { This article is distributed exclusively by Cold Spring Harbor Laboratory Press for the } \\ \text { first } 12 \text { months after the full-issue publication date (see } \\ \text { http://learnmem.cshlp.org/site/misc/terms.xhtml). After } 12 \text { months, it is available under } \\ \text { a Creative Commons License (Attribution-NonCommercial } 4.0 \text { International), as } \\ \text { described at http://creativecommons.org/licenses/by-nc/4.0/. }\end{array} \\ & \begin{array}{l}\text { Receive free email alerts when new articles cite this article - sign up in the box at the } \\ \text { top right corner of the article or click here. }\end{array} \\ & \begin{array}{c}\text { Service } \\ \text { Serting }\end{array}\end{aligned}$

